\title{
The episodic geomorphological-sedimentary evolution of different basins in the Fenwei Graben and its tectonic implication
}

\author{
HU Xiaomeng, ZHOU Tianhang, CAI Shun \\ Geography Department, Shanghai Normal University, Shanghai 200234, China
}

\begin{abstract}
There are a series of basins in the Fenwei Graben. Field survey found that there took place several paleolake regressions or intensive stream down-incisions in all basins during the Mid-Late Quaternary. The lowest and oldest paleosol/loess units overlying three of the lacustrine terraces or alluvial ones and some paleomagenetism data from the lacustrine sediment indicate that the onset times of three paleolake regressions or intensive stream down-incisions are synchronous with the formation of $L_{9}, L_{6}$ and $L_{2}$ respectively in the Weihe Basin, $S_{8}, S_{5}$ and $S_{1}$ respectively in the Linfen-Taiyuan-Xingding Basins, and $L_{8}, L_{5}$ and $L_{1}$ respectively in the Datong Basin. The difference in the onset time of each lake regressions or intensive stream down-incision in different basins reveals that the farther the basin is from the Tibetan Plateau, the later it took place. Taking these field facts and the former research results in terms of the regional tectonic movement into account, it is inferred that the tectonic movement of the Tibetan Plateau most probably controlled such geomorphologicalsedimentary evolution in the graben.
\end{abstract}

Keywords: Fenwei Graben; lacustrine and alluvial terrace; paleolake regression; Tibetan Plateau

\section{Introduction}

China is topographically composed of three steps - I, II and III - which decline sequentially in elevation from west to east (Figure 1). Step I is the Tibetan Plateau (TP) with an average elevation of ca. $4500 \mathrm{~m}$, being the highest of the three. It has been subject to tectonic uplift during the Cenozoic because of the collision of the Indian and Eurasian plates (Harrison et al., 1992; Coleman, 1995). Over the latest two decades, the uplift of the TP during the Late Cenozoic has attracted considerable scientific attention and the published literatures have documented multiple severe episodes of tectonic uplift experienced by the TP (Li et al., 1996; Cui et al., 1998; Wu et al., 2001). Apart from these researches, many scientists have concentrated upon the impact the TP uplift had on the regional climate change, particularly the change of East Asian monsoon (Xue et al., 1998; An et al., 2001; Shen et al., 2004; Li et al., 2014). However, there have been few studies of the effect of the TP uplift on landform

Received: 2017-06-05 Accepted: 2017-07-06

Foundation: National Natural Science Foundation of China, No.41371021

Author: Hu Xiaomeng, Professor, specialized in geomorphology and Quaternary research. E-mail: hxm@shnu.edu.cn 
development, particularly in some regions far away from the TP (Pan et al., 2011, 2012; Shi et al., 2015; Hu et al., 2016).

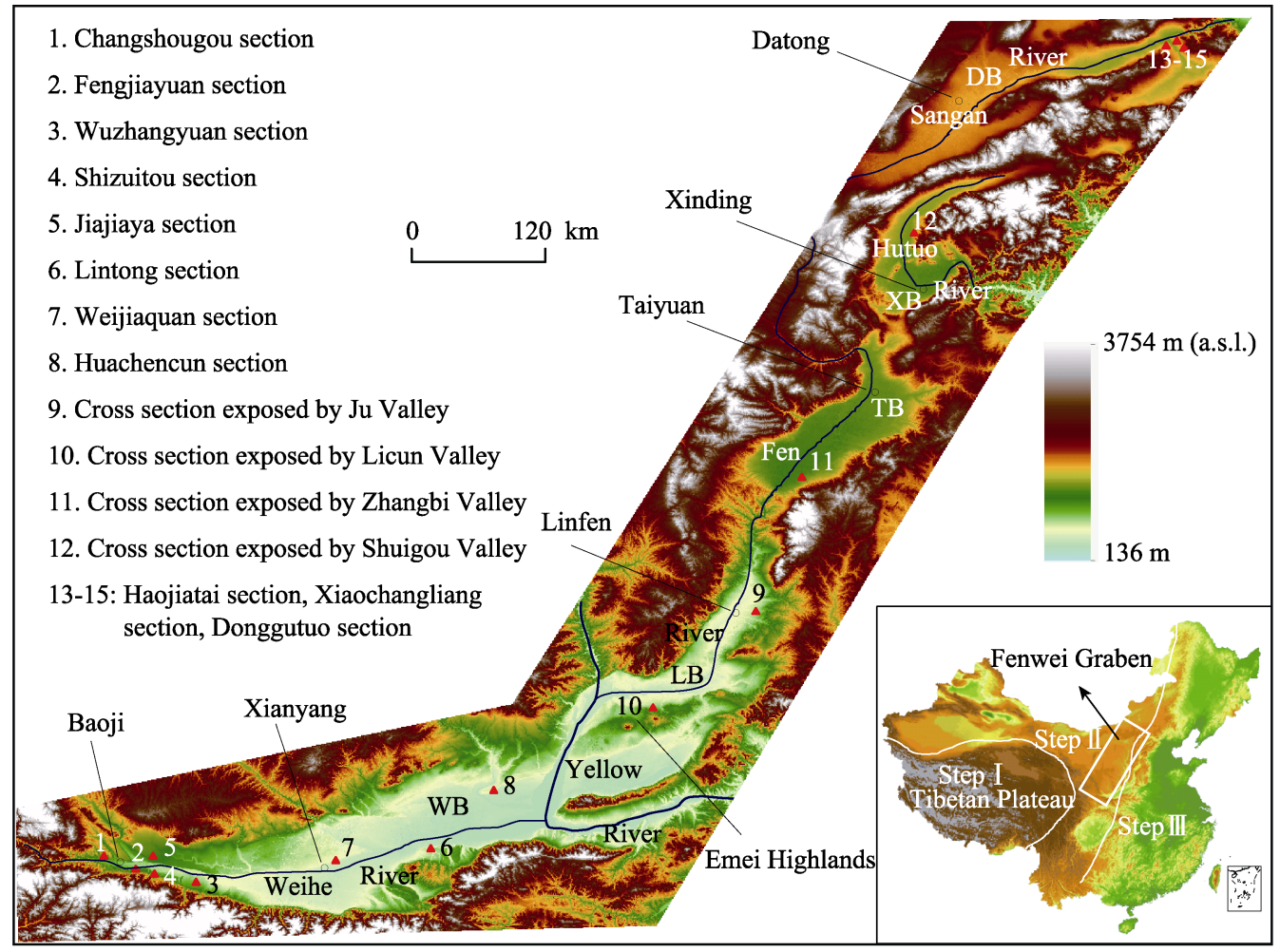

Figure 1 The map showing the landform and the locations of surveyed sections in the Fenwei Graben

The Fenwei Graben is located some distance to the northeast of the TP on Step II. It extends $\sim 1700 \mathrm{~km}$ from southwest to northeast and is composed of a series of basins which are arrayed in an "S" shape and separated from each other by mountains and/or highlands. From southwest to northeast, they are the Weihe Basin (WB), the Linfen Basin (LB), the Taiyuan Basin (TB), the Xinding Basin (XB) and the Datong Basin (DB) (Figure 1). The Fenwei Graben was tectonically active during the Late Cenozoic (Chen, 1987; Wang, 1987; Zhang et al., 1995; Zhang et al., 1998, Qu et al., 2014; Yang et al., 2014). Previous research has demonstrated that some geomorphological events in some basins of the Graben coincided with some TP uplift episodes such as "Kunlun-Huanghe Movement" and "Gonghe Movement" during the Quaternary (Li et al., 1996; Cui et al., 1998; Wang et al., 2001; Hu et al., 2005). This would suggest that landform development in the Graben was most likely controlled by the tectonic movements of the Plateau, although there is at present little additional evidence to confirm this.

In this paper, we focus on the surveys of the river and lake terrace sequences in the WB, the $\mathrm{LB}$, the TB, and the XB, and of changes in the lacustrine sedimentary rhythms of the DB. On the basis of the results of detailed field surveys, we elucidate the temporal differences in the episodic geomorphological-sedimentary evolution of these basins during the Mid-Late Quaternary. Furthermore, we analyze the factors which controlled the formation of these geomorphological-sedimentary features and any differences in the onset times of their evo- 
lutionary sequences. The aim of this research is to provide new evidence to help prove that the tectonic uplift of the TP governed the Fenwei Graben's geomorphological-sedimentary development at this time.

\section{Geographical and geological setting}

The Fenwei Graben is located in the southern and eastern Chinese Loess Plateau. Its climate is dominated by the East Asian monsoon. Most of the region's precipitation is brought by the warm and moist summer monsoon, whereas the cold and dry winter monsoon causes intense dust storms and loess deposition. The land surface is thus covered by a thick layer of loess (Liu, 1985; An et al., 1991a, 1991b). The Weihe River, the Fen River, the Hutuo River and the Sangan River flow across the Weihe Basin, the Taiyuan Basin and the Linfen Basin, the Xinding Basin, and the Datong Basin, respectively. Because of the constraint of some mountains or highlands, these rivers belong to different drainage basins. During the Quaternary, all these basins were occupied by outflow lakes, which experienced many regressions and transgressions (Mo, 1991; Xia, 1992; Wang et al., 1996; Hu et al., 2005). The area therefore saw the development of thick lacustrine sedimentary (in addition to alluvial) deposits and landforms.

Geologically, the graben came out in the Cenozoic under the control of tectonic extension, and the Weihe Basin, being in the southwestmost of the graben and nearer to the TP than the other basins, began to form in the Paleocene, and the other basins did in the Pliocene. The upper mantle underneath the graben uplifts relative to that underneath its surrounding mountains or highlands, and there occurs high heat flow in the graben basins (RGSSB, 1988); some of the basins experienced several episodic intensive volcano eruptions during the Mid-Late Quaternary (Li et al., 1998). The Graben is bounded by a series of neotectonically active normal faults in the surrounding mountains and highlands. Many alluvial terraces extending across these boundary faults are offset laterally and vertically; the vertical displacement of Neogene gravels during the Quaternary along some primary boundary faults reaches $\sim 2500 \mathrm{~m}$, with a lateral displacement of $\sim 12.5 \mathrm{~km}$ (Hu et al., 2010). In addition, the Graben's basins have experienced some great earthquakes during recorded history, e.g., the 1556 Huaxian Earthquake in the WB, the 1303 Hongdong Earthquake and the 1695 Linfen Earthquake in the LB, and 1038 Dingxiang Earthquake in the XB, all of which had estimated magnitudes of $>7.0$.

\section{Methods}

To constrain the ages of the studied landforms and sedimentary sequences, we adopted loess/paleosol sequence and paleomagnetic methods.

Loess sections in northwestern China are composed of less-weathered massive brown loess units and red maturely weathered soil units, forming a loess/paleosol sequence, and constituting a continuous terrestrial record of changing climatic conditions spanning more than two million years (Liu, 1985). Each of the loess and paleosol units in the sequence has been dated (Liu, 1985; Kukla and An, 1989; Ding et al., 1994) and can be used as a distinctive regional stratigraphic horizon of known age to constrain the ages of some sediments and landforms (Porter et al., 1992). 
Loess/paleosols were deposited on the surfaces of lacustrine and/or alluvial terraces in the $\mathrm{WB}$, the LB, the TB and the XB after their formation. Therefore, by dating the stratigraphic unit of the loess or paleosol just above the landform, we can constrain the age of that particular landform.

The accurate identification of each loess/paleosol unit relies on its distinctive physical characteristics (e.g., texture, structure, thickness, color, paleomagnetism and magnetic susceptibility) as well as its stratigraphic position in the regional succession. For instance, $\mathrm{S}_{5}$, being a special aeolian layer in northwestern China, is a paleosol complex with a distinctively greater thickness, darker brown color and thicker clay coating than other paleosol units (Han et al., 1998), with four other prominent paleosols $\left(\mathrm{S}_{4}, \mathrm{~S}_{3}, \mathrm{~S}_{2}, \mathrm{~S}_{1}\right)$ usually found above it. It is easy to be identified in the field. In loess/paleosol sections, the magnetic susceptibility of paleosols is much greater than that of loess. The Brunhes-Matuyama polarity boundary $(\mathrm{B} / \mathrm{M})$ is located in the loess layer $\mathrm{L}_{8}$; loess/paleosol units younger and older than $\mathrm{L}_{8}$ display a normal Brunhes polarity and a reversed Matuyama polarity, respectively (Yue and Xue, 1996). Using paleomagnetism to determine the B/M boundary in a loess/paleosol section can help us delineate $\mathrm{L}_{8}$ and other loess/paleosol units.

Changes in the lacustrine sedimentary rhythm in the DB display stacked regressive/transgressive sequences, recording past lake level drops and rises. Paleomagnetism can also be used to determine the $\mathrm{B} / \mathrm{M}$ boundary in the lacustrine sections, and hence to constrain the onset times of some lake regression sequences.

There exist prominent characteristic differences between loess/paleosol stratigraphies and lacustrine sediment. Besides color difference, loess/paleosol stratigraphies exhibit no bedding, but lacustrine sediment does; a paleosol layer has pedogenic horizons (e.g., argillic and calcic horizons), but lacustrine sediment does not. It is therefore easy to distinguish the two kinds of deposition with the naked eye even in the field.

Prior to our field surveys, we analyzed topographic maps (scale: 1:50,000) and satellite images of the basins to determine which focal valleys should be investigated in greater detail. We therefore conducted research along some deeply-incised valleys, extending from the margins of each basin to its center, in order to trace the lacustrine sediment and find the lowest loess or paleosol unit immediately overlying it. In the field, paleomagnetic samples and magnetic susceptibility values were derived from both the overlying loess/paleosol strata and the lacustrine sediment; each of magnetic susceptibility samples was taken at an interval of $10 \mathrm{~cm}$ and paleomagnetic ones were mostly selected at intervals of $100 \mathrm{~cm}$, but with some taken at $30 \mathrm{~cm}$ intervals near the inferred reversal of the paleomagnetic field. All palaeomagnetic samples were measured in Nanjing University, China; all magnetic susceptibility samples were tested using an MS2 system in Shanghai Normal University, China.

\section{Some graben geomorphological-sedimentary features}

\subsection{Geomorphological-sedimentary features of the Weihe Basin}

The WB extends $\sim 300 \mathrm{~km}$ from approximately west to east, and is up to $40 \mathrm{~km}$ wide. The Weihe River flows from west to east across the basin (Figure 1). The incised valleys of the Weihe River and its tributaries expose the sedimentary features of the different terraces in the basin. These exposed sections indicate no lacustrine sediment in the upper reaches of the 
Weihe River east of Xianyang, but rather two sets of alluvial deposits along each side of the river, forming five river terraces in all. In the lower reaches of the river, we see both lacustrine and younger alluvial sedimentary deposits, forming two lacustrine terraces and two alluvial ones.

\subsubsection{Geomorphological-sedimentary sections in the upper reaches of the Weihe River}

The Changshougou Section $\left(\mathrm{N} 34^{\circ} 23.5^{\prime}, \mathrm{E} 107^{\circ} 06.7^{\prime}\right)$, a typical section of alluvial terrace $\mathrm{T}_{5}$ in the upper reaches of the river, is located on the north bank of the Weihe River, $\sim 1 \mathrm{~km}$ west of Baoqi. From the base of the section upward, the sedimentary sequence consists of sedimentary rock, loess/paleosols of the Early Quaternary $\left(\mathrm{Q}_{1}\right)$, alluvial terrace sediment, and loess/paleosols of the Mid-Late Quaternary $\left(\mathrm{Q}_{2}-\mathrm{Q}_{3}\right)$; there exists an eroded surface between the alluvial sediment and the underlying $\mathrm{Q}_{1}$ loess/paleosols (Figure 2a). The terrace sediment is of alluvial rounded gravels $\sim 10$ m thick, with several intercalated thin sand layers, and its surface is $\sim 130 \mathrm{~m}$ high above the present Weihe River level. The loess/paleosol stratigraphy overlying the terrace is $\sim 70 \mathrm{~m}$ thick, and shows eight distinct paleosol units, with the lowest loess/paleosol unit deposited directly on top of the terrace being a loess unit. The paleomagnetic results show that the B/M boundary is located in the loess unit between the eighth paleosol unit and the seventh one, implying that the loess unit is $\mathrm{L}_{8}$, and that the eighth paleosol unit is $\mathrm{S}_{8}$. The lowest loess unit overlying the terrace can therefore be inferred as $\mathrm{L}_{9}$, indicating that this river terrace formed when $\mathrm{L}_{9}$ was depositing.

The Fengjiayuan and Wuzhangyuan sections are typical $\mathrm{T}_{4}$ sections. The Fengjiayuan

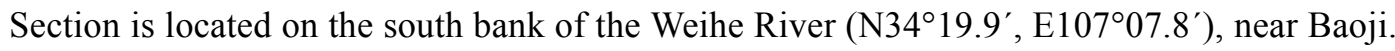
This river terrace is $\sim 65 \mathrm{~m}$ high above the present river level and is composed of rounded gravels of $\sim 3-5 \mathrm{~cm}$ in diameter, with some sand lenses present. The thickness of the gravel layer is $\sim 8 \mathrm{~m}$. Underlying the terrace is granite, and overlying it is a $40 \mathrm{~m}$-thick loess/paleosol stratigraphy, the lowest layer of which is a $\sim 80 \mathrm{~cm}$-thick loess unit. There are five distinct paleosols in the loess/paleosol stratigraphy; the fifth paleosol is a soil complex composed of three pedons of a greater thickness, and a darker brown color and thicker clay coatings than the other four paleosol units. It is inferred to be $S_{5}$. The loess unit below it is $\mathrm{L}_{6}$, implying that this river terrace developed when $\mathrm{L}_{6}$ was depositing. The Wuzhangyuan Section is also located on the south bank of the river $\left(\mathrm{N} 34^{\circ} 15.9^{\prime}, \mathrm{E} 107^{\circ} 36.8^{\prime}\right)$, about $42 \mathrm{~km}$ to the east of Baoji. The height of the terrace here is $\sim 60 \mathrm{~m}$ above the present river level. The terrace sediment is composed of highly rounded gravels, whose diameters are mostly $2-5 \mathrm{~cm}$ (with the biggest being $15 \mathrm{~cm}$ ). The thickness of the exposed sediment is $\sim 10 \mathrm{~m}$, and it contains an interbedded laminated silt and clay layer, though this layer's lower part remains unexposed. A $\sim 40 \mathrm{~m}$-thick loess/paleosol stratigraphy overlies the terrace surface, of which the lowest and oldest loess unit is $\mathrm{L}_{6}$ (based on the identification of $\mathrm{S}_{5}$ in the section).

The Shizuitou and Jiajiaya sections are typical $\mathrm{T}_{3}$ sections. The Shizuitou Section is found on the south bank of the Weihe River near Baoji; the height of the terrace is $\sim 30 \mathrm{~m}$ above the present river level. The exposed terrace gravels are $\sim 25 \mathrm{~m}$ thick. A $\sim 15 \mathrm{~m}$-thick loess/paleosol stratigraphy has been deposited on the terrace surface, of which the lowest is a loess unit immediately above the terrace; one prominent paleosol has developed in it. Based on the magnetic susceptibility curve, we determined this prominent paleosol as $\mathrm{S}_{1}$; the 


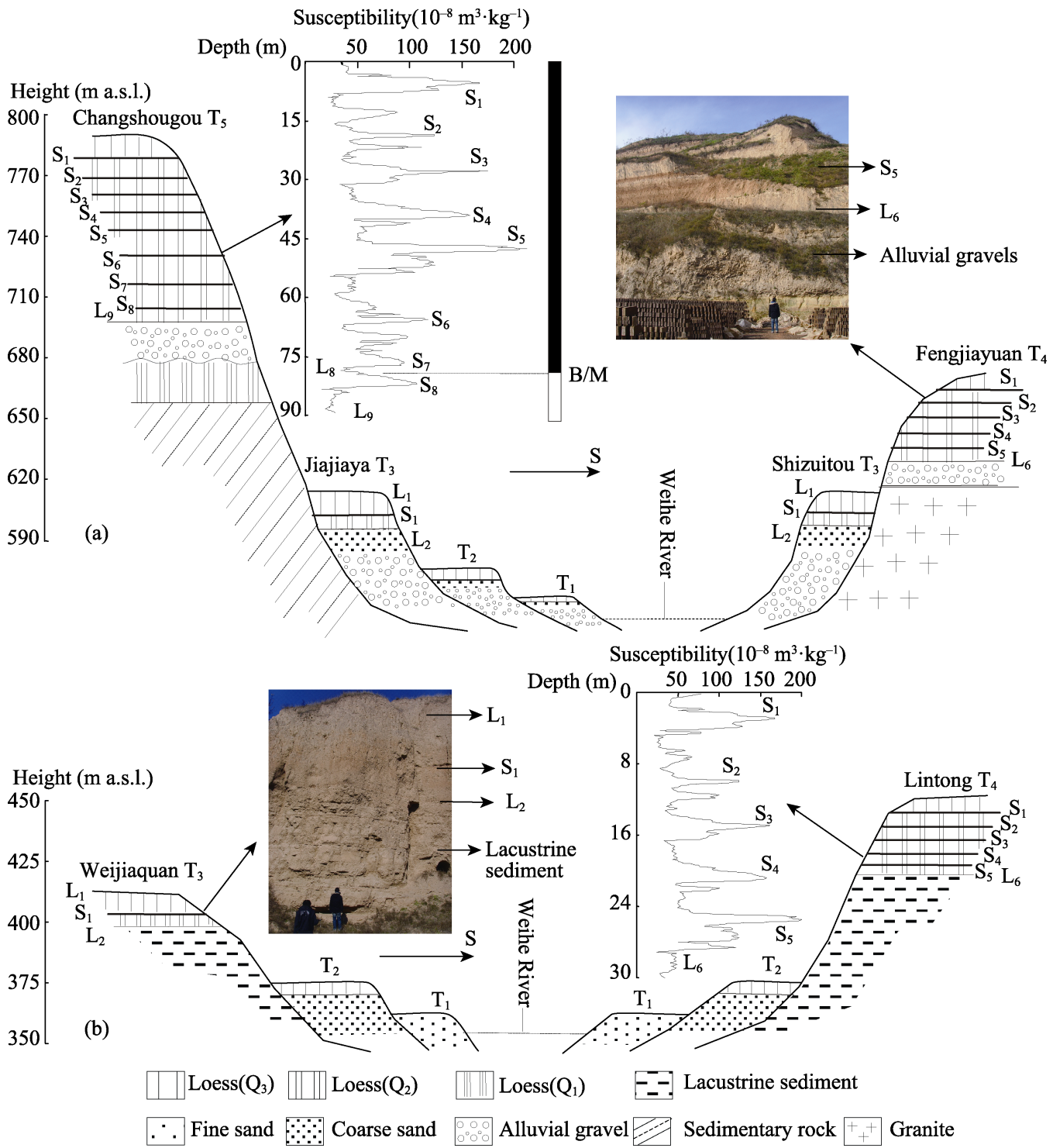

Figure 2 Geomorphological-sedimentary cross-sections in the upper reach (a) and the lower one (b) in the Weihe Basin

loess unit below it is $\mathrm{L}_{2}$. The Jiajiaya Section is located on the north bank of the river, about $10 \mathrm{~km}$ to the east of Baoji $\left(\mathrm{N} 34^{\circ} 20.4^{\prime}, \mathrm{E} 107^{\circ} 18.3^{\prime}\right)$. The terrace height is $\sim 25 \mathrm{~m}$ above the present river level and the exposed alluvial sediment is $\sim 6 \mathrm{~m}$ thick, of which the lower part is valley gravels, and the upper floodplain deposits; $13 \mathrm{~m}$-thick loess/paleosol strata $\mathrm{L}_{2}$ and $\mathrm{S}_{1}$ overlie the terrace. $\mathrm{T}_{2}$ and $\mathrm{T}_{1}$ are $12 \mathrm{~m}$ and $5 \mathrm{~m}$ above the present river level, respectively; both are capped by $\mathrm{L}_{1}$.

\subsubsection{Geomorphological-sedimentary sections in the lower reaches of the Weihe River}

The stepped nature of the landforms beside the Weihe River is clear to see in its lower reaches (Figure 2b). The Lintong Section, located on the south bank of the Weihe River, is exposed by brickworks $\sim 5 \mathrm{~km}$ east of Lintong (N34⒉ $\left.25.3^{\prime}, \mathrm{E} 109^{\circ} 16.7^{\prime}\right)$. This section shows 
the composition of the $\mathrm{T}_{4}$ sedimentary profile. Its lower part is composed of laminated grey-green fine sand, silt and clay, which were deposited in a paleolake, implying that $\mathrm{T}_{4}$ here is a lacustrine terrace; the thickness of this exposed lacustrine sediment is $\sim 38 \mathrm{~m}$, and the top surface of the sediment is $\sim 60 \mathrm{~m}$ above the present river level. Overlying the lacustrine sediment is a $\sim 30 \mathrm{~m}$-thick loess/paleosol stratigraphy, in which there have developed five prominent paleosols; the lowest layer directly deposited on the lacustrine terrace is a loess unit. We took magnetic susceptibility samples from the overlying loess/paleosol strata in the field. Based on the magnetic susceptibility features of the loess/paleosol strata, and the features of the fifth paleosol, which is complex and consists of three pedons, we inferred that the fifth paleosol is $\mathrm{S}_{5}$, and the lowest loess unit is $\mathrm{L}_{6}$, indicating that the paleolake regression took place synchronously with the formation of $\mathrm{L}_{6}$.

$\mathrm{T}_{3}$ is also a lacustrine terrace in this sector, with typical sections being the Weijiaquan and Huachencun sections. The Weijiaquan Section is an artificial exposure, located next to a brickworks on the north bank of the river (N34²0.6', E108 $\left.39.7^{\prime}\right)$. The lower part of the section is composed of laminated grey-green silty clay, with interbedded pale-yellow silt and fine sand; some snail shell fossils are scattered throughout the lacustrine terrace. The height of the top surface of the terrace is $\sim 40 \mathrm{~m}$ above the present river level. A $\sim 15 \mathrm{~m}$-thick loess/paleosol stratigraphy overlies the terrace, and the lowest layer, in direct contact with the lacustrine terrace, is a loess unit. There is only one distinctive paleosol in the loess/paleosol stratigraphy, which is complex, with a reddish-brown color. It is inferred to be $\mathrm{S}_{1}$; the lowest loess unit is inferred to be $\mathrm{L}_{2}$. The Huachencun Section (N34 $53.9^{\prime}$, E109 $47.5^{\prime}$ ) shows the same sedimentary features as the Weijiaquan Section. The lower part is composed of lacustrine sediment, with well-developed horizontal beddings; the upper part is a loess/paleosol stratigraphy, of which the oldest and lowest layer is $\mathrm{L}_{2}$. The height of the lacustrine terrace surface is $\sim 38 \mathrm{~m}$ above the present river level.

Two younger alluvial terraces can be identified in some artificial and natural exposures close to today's Weihe River, and both are overlain by $\mathrm{L}_{1}$ aeolian sediment.

\subsection{Geomorphological-sedimentary features of the three basins of Linfen, Taiyuan and Xinding}

\subsubsection{Geomorphological-sedimentary features of the Linfen Basin}

The LB is a reversed " $\mathrm{L}$ " in shape, extending NNE to SSW in its northern sector, with a length of $\sim 80 \mathrm{~km}$, and a width of up to $40 \mathrm{~km}$; and ENE to WSW in its southern sector, with a length of $\sim 60 \mathrm{~km}$, and a width of $\sim 30 \mathrm{~km}$ (Figure 1).

In its northern sector, there is an extensive platform $\sim 20 \mathrm{~km}$ in width to the east of the Fen River. The Ju valley, a tributary of the Fen River, is incised into the platform, exposing its geomorphological-sedimentary features. Field surveys reveal that the platform is composed of three lacustrine terraces, each with different heights and different loess/paleosol sequences overlying them (Figure 3a).

The highest terrace is $\sim 4 \mathrm{~km}$ wide from east to west, and $\sim 110 \mathrm{~m}$ above the present Fen River level. Its eastern boundary is a normal fault which separates it from the Fushan Highlands and defines the eastern margin of the basin. The base of the terrace is composed of lacustrine sediment, which is composed of laminated grey-green silt and fine sand. The thickness of the exposed lacustrine deposit is $\sim 30 \mathrm{~m}$, but its lower part remains unexposed. 

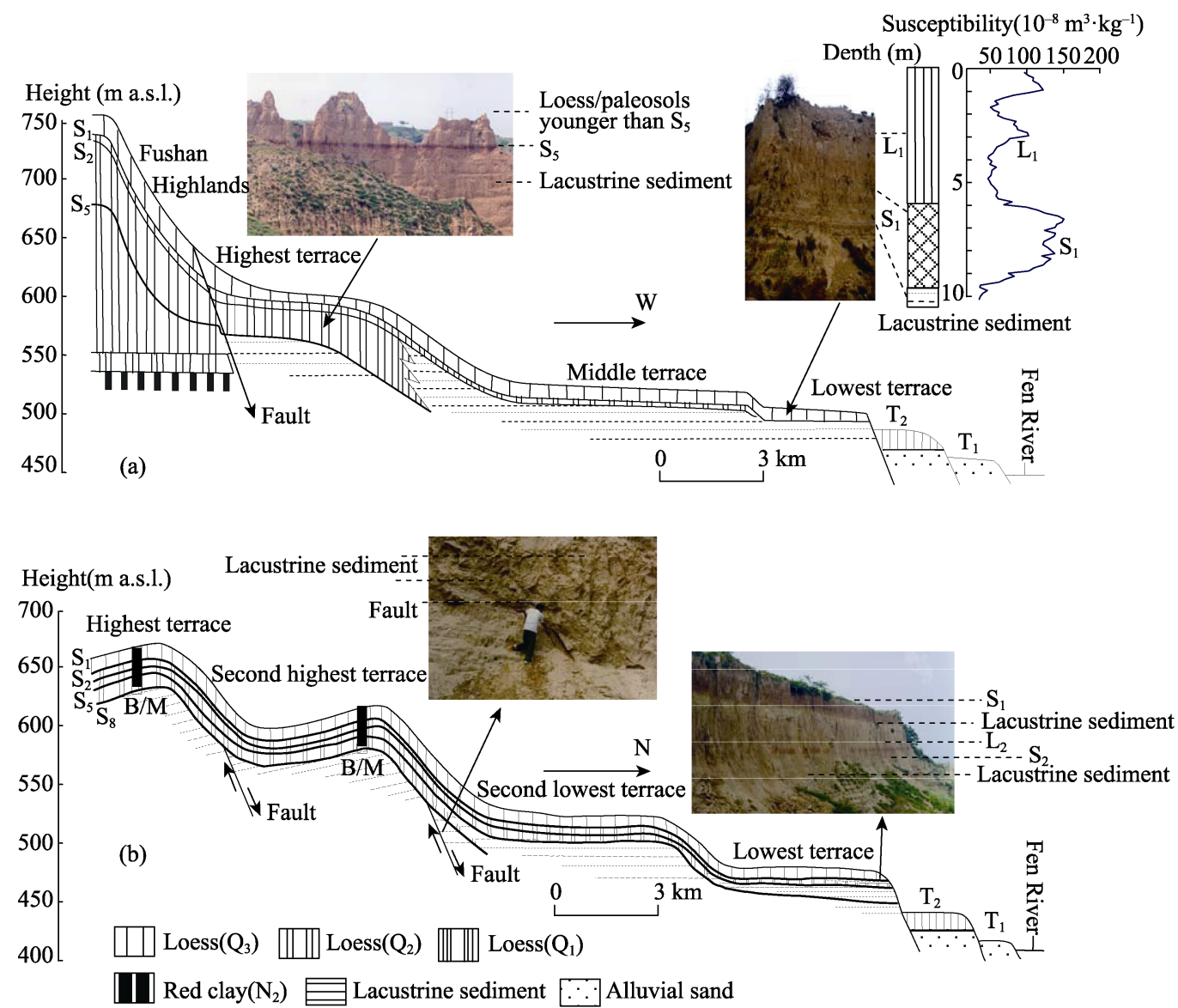

Figure 3 Geomorphological-sedimentary cross-sections in the northern sector (a) and the southern one (b) of the LB

The loess/paleosol stratigraphy overlying the terrace is up to $30 \mathrm{~m}$ thick, and includes five well-developed paleosols. The lowest loess/paleosol unit, developed directly on the top of the lacustrine sediment, is the fifth paleosol. This paleosol displays a darker, more reddish-brown color and thicker clay coatings than the four others; it is inferred to be $\mathrm{S}_{5}$. At the front of this terrace, $\mathrm{S}_{5}$ extends and dips toward the lower terrace, and is partially capped by the lower lacustrine sediment, before finally dying out.

The middle terrace is $\sim 8 \mathrm{~km}$ wide and $60 \mathrm{~m}$ above the present level of the Fen River. It is composed of laminated silt and fine sand, with interlayered clay forming its base. A 15 m-thick loess/paleosol stratigraphy has been deposited on the surface of the terrace, where two prominent paleosols have developed. The lowest loess/paleosol unit above the lacustrine sediment is inferred to be $\mathrm{S}_{2}$, based on its stratigraphic position in the loess/paleosol succession, as well as its magnetic susceptibility features.

The lowest terrace is $\sim 3 \mathrm{~km}$ wide from east to west, and lies $45 \mathrm{~m}$ above the Fen River's present level. The terrace base is also composed of laminated clay, silt and fine sand. There is a $\sim 10 \mathrm{~m}$-thick loess/paleosol stratigraphy overlying the lacustrine sediment; the lowest unit is a paleosol. From its magnetic susceptibility features, this paleosol is inferred to be $\mathrm{S}_{1}$.

Besides these three lacustrine terraces, there are two well-developed alluvial terraces 
within the basin, both of which are lower in height than the lowest lacustrine terrace.

The Emei Highlands form the southern boundary of the basin (Figure 1). Four descending lacustrine terraces are discernible from the highland margins to the center of the basin. The Licun Valley is a long, deeply-incised valley which cuts across these terraces and thus clearly shows their geomorphological-sedimentary differentiation (Figure 3b).

The highest lacustrine terrace surface is 210-220 m above the present Fen River level; the loess/paleosols overlying the lacustrine sediment are $\sim 48 \mathrm{~m}$ thick. Of these, the lowest loess/paleosol unit is a reddish paleosol. The second highest terrace is $160-170 \mathrm{~m}$ above the Fen River's present level, and is overlain by loess/paleosols $\sim 50 \mathrm{~m}$ thick; the lowest loess/paleosol unit is also a paleosol. Paleomagnetic samples were taken from the overlying loess/paleosol strata. Paleomagnetic results show that the lowest paleosol unit overlying the two terraces is $\mathrm{S}_{8}$, indicating that both terraces were almost concurrently exposed subaerially. The present-day surfaces of the two terraces are southward-tilting reverse slopes, with normal faults between them and in front of the second highest terrace. The difference in elevation between the two terraces may have resulted from the tectonic movement of the normal fault between them. At the front of the second highest terrace, the $\mathrm{S}_{8}$ paleosol can be seen to dip toward, and extend into, the lower terrace's lacustrine sediment before petering out.

The second lowest terrace is $\sim 110 \mathrm{~m}$ above the present Fen River level, and is overlain by a loess-paleosol stratigraphy $\sim 30 \mathrm{~m}$ thick. The lowest aeolian sediment in direct contact with the lacustrine sediment is a mauve paleosol layer, with a well-developed manganese membrane. Owing to its significant clayification, mauve appearance and stratigraphic position within the loess/paleosol succession, it can be identified as $\mathrm{S}_{5}$. At the front of this terrace, this paleosol dips toward the lower terrace and extends into the lowest terrace's lacustrine sediment. A further tracing survey taken downvalley found that $\mathrm{S}_{5}$ extends nearly to the center of the basin and occurs in sections near the present Fen River, where a layer of younger lacustrine sediment up to $26 \mathrm{~m}$ thick overlies it.

The lowest terrace is $\sim 50-40 \mathrm{~m}$ above the present Fen River level, with marked differences in the sedimentary features of its far side and frontage. At the far side of the terrace, an exposed vertical section shows that the underlying sediments (from bottom to top) are old lacustrine, $\mathrm{S}_{5}$, young lacustrine, $\mathrm{S}_{2}, \mathrm{~L}_{2}, \mathrm{~S}_{1}$, and $\mathrm{L}_{1}$ in turn; the sedimentary stratigraphy at the terrace frontage (from bottom to top) runs through old lacustrine, $\mathrm{S}_{5}$, young lacustrine, $\mathrm{S}_{2}, \mathrm{~L}_{2}$, younger lacustrine, $\mathrm{S}_{1}$, and $\mathrm{L}_{1}$ in turn (Figure $3 \mathrm{~b}$ ), with a layer of celadon lacustrine sediment covering $\mathrm{L}_{2}$ and underlying $\mathrm{S}_{1}$. This terrace can therefore be divided into two sub-terraces: one is directly capped by $\mathrm{S}_{2}$, and the other by $\mathrm{S}_{1}$.

Two alluvial terraces also developed in this sector after the formation of the lowest lacustrine terrace.

\subsubsection{Geomorphological-sedimentary features of the Taiyuan Basin}

The TB extends from NE to SW, with a length of $\sim 120 \mathrm{~km}$, and a width of up to $40 \mathrm{~km}$ (Figure 1). There is a lacustrine platform in its southeastern part. The deeply-incised Zhangbi Valley exposes its geomorphological-sedimentary features. This platform is composed of three lacustrine terraces, and their surfaces decrease step by step in height from upvalley to downvalley. Loess/paleosol strata of different sequences and thicknesses have been deposited on the surfaces of these terraces (Figure $4 \mathrm{a}$ ).

The highest terrace is $\sim 120 \mathrm{~m}$ above the present Fen River level; its lacustrine sediment is 
composed of bedded celadon silt and fine sand, with some fragments of snail shells. A nearly 50 m-thick aeolian sedimentary layer has been deposited on this terrace; eight paleosols can be identified in the loess/paleosol section. The eighth, or lowest, paleosol has developed directly on the surface of the lacustrine sediment. Beneath the lacustrine sediment is another older paleosol. Paleomagnetic results show that the eighth paleosol overlying the lacustrine sediment is $\mathrm{S}_{8}$. The middle terrace stands about $40 \mathrm{~m}$ lower than the highest one; the lacustrine sediment of the terrace base is composed of compacted grey clay and silt, locally interlayered with fine sand. The loess/paleosol sediment overlying this terrace is $\sim 30 \mathrm{~m}$ thick, and $\mathrm{S}_{5}$ has developed directly on its surface.

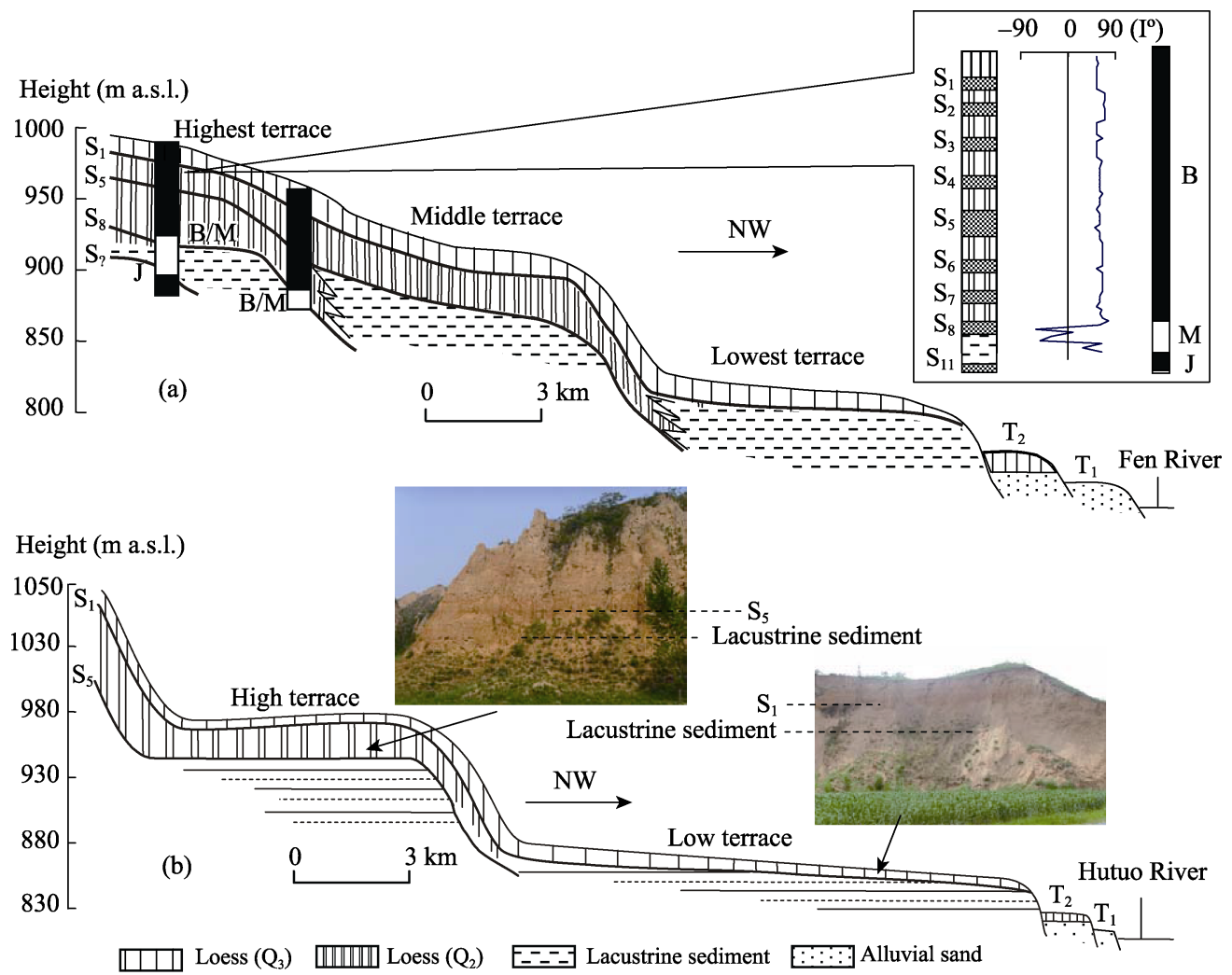

Figure 4 Geomorphological-sedimentary cross-section in the Taiyuan Basin (a) and Xinding Basin (b) I: Magnetism Inclination; J: Jaramillo Normal Polarity Subzone

The lowest terrace is $\sim 60 \mathrm{~m}$ lower than the middle one, and is overlain by a loess/paleosol stratigraphy $\sim 15 \mathrm{~m}$ thick. The lacustrine sediment of this terrace is composed of silt and light-colored fine sand, with many snail shell fragments. The lowest paleosol in the overlying loess/paleosol stratigraphy is $\mathrm{S}_{1}$. We did not find a lacustrine terrace on this platform correspondent to that in the LB, i.e. proximally capped by $\mathrm{S}_{2}$.

There are, in addition, two younger and lower alluvial terraces along the present Fen River.

\subsubsection{Geomorphological-sedimentary features of the Xinding Basin}

The XB is a "C" in shape, extending NNE-SSW in its northern sector, and SW-NE in its southern one. It is $\sim 120 \mathrm{~km}$ in length, and $20-40 \mathrm{~km}$ in width, and the Hutuo River flows across the basin (Figure 1). There is a lacustrine platform to the east of the Hutuo River in 
the northern sector of the basin; the Shuigou Valley is incised into it, uncovering the platform's geomorphological-sedimentary features. The stepped landforms and differences between the overlying loess/paleosol sequences within the lacustrine sedimentary profiles show that this lacustrine platform is composed of two lacustrine terraces (Figure 4b). The higher lacustrine terrace is $\sim 100 \mathrm{~m}$ above the present Hutuo River level, and is composed of laminated, and somewhat compacted, grey-green clay and silt. Overlying the terrace is a $\sim 30$ $\mathrm{m}$-thick loess/paleosol stratigraphy, in which five paleosols have developed, the lowest being $\mathrm{S}_{5}$. The lower lacustrine terrace is $\sim 45 \mathrm{~m}$ above the present Hutuo River level and is composed of laminated silt and fine sand, intercalated with thin bright-reddish clay layers. This lacustrine sediment is somewhat loose. A $\sim 12$ m-thick loess/paleosol stratigraphy has been deposited on this terrace, with the lowest paleosol being a prominent $\mathrm{S}_{1}$. Additionally, two young alluvial terraces have also developed.

There may have been intensive erosion of this lacustrine platform in the basin in the past; we did not find any lacustrine terraces which corresponded to those directly capped by $\mathrm{S}_{8}$ and $\mathrm{S}_{2}$ in the LB.

\subsection{Sedimentary features of the Datong Basin}

The DB extends from approximately west to east, to a length of $\sim 250 \mathrm{~km}$ and a width of 20-30 km. The Sangan River flows from west to east across the basin (Figure 1). Because of the deposition of proluvial fans from the surrounding mountains, the lacustrine landforms in the basin have become partly modified and any stepped terraces blurred, but some exposed sedimentary sections do nevertheless show changes in the lacustrine sedimentary rhythm, indicating past paleolake level changes. In the southeastern part of the basin, the down-incision of the Sangan River has exposed three thick sedimentary sections: the Haojiatai Section $\left(40^{\circ} 13.4^{\prime} \mathrm{N}, 114^{\circ} 39.5^{\prime} \mathrm{E}\right)$; the Xiaochangliang Section $\left(40^{\circ} 13^{\prime} \mathrm{N}, 114^{\circ} 39.7^{\prime} \mathrm{E}\right)$; and the Donggutuo Section $\left(40^{\circ} 13.3^{\prime} \mathrm{N}, 114^{\circ} 39.9^{\prime} \mathrm{E}\right)$. Many paleolithic relics have been found in these sections (You et al., 1980; Tang et al., 1995). The three sections are located at the center, near-shore area and the lakeside of the paleolake, respectively, and the lowest exposed sedimentary layers were initially deposited in 1.66 MaBP, $1.38 \mathrm{MaBP}$ and 1.10 MaBP, respectively (Yang, 2000; Zhu et al., 2001, 2004). We made detailed surveys of the sedimentary rhythms of these three sections, and used paleomagnetic methods to date their upper parts (Figure 5).

The exposed sediment of the Haojiatai Section is $\sim 122 \mathrm{~m}$ thick, and exhibits five sedimentary rhythmic cycles. Each rhythmic cycle begins with sand, or sand with some small gravels, and gradually changes into fine sand, silt and clay in an upward direction, displaying a classic lake regression-transgression sedimentary sequence. The sedimentary layers from $122.3 \mathrm{~m}$ to $110.2 \mathrm{~m}, 110.2 \mathrm{~m}$ to $72.7 \mathrm{~m}, 72.7 \mathrm{~m}$ to $50.5 \mathrm{~m}, 50.5 \mathrm{~m}$ to $34.1 \mathrm{~m}$, and 34.1 $\mathrm{m}$ to $9.8 \mathrm{~m}$ in depth constitute the fifth, fourth, third, second and first sedimentary rhythm sequences, respectively. Overlying the lacustrine sediment is $\sim 10 \mathrm{~m}$ thick loess layer $\mathrm{L}_{1}$. Paleomagnetic results show that the $\mathrm{B} / \mathrm{M}$ boundary is located at the base of the second sedimentary rhythmic sequence. The base of the Xiaochangliang Section is composed of volcanic rock. The lacustrine sediment overlying this rock is $\sim 64 \mathrm{~m}$ thick, and four sedimentary rhythmic cycles can be identified. The sedimentary layers from $64.3 \mathrm{~m}$ to $42.2 \mathrm{~m}$, $42.2 \mathrm{~m}$ to $29.9 \mathrm{~m}, 29.9 \mathrm{~m}$ to $19.2 \mathrm{~m}$, and $19.2 \mathrm{~m}$ to $7.3 \mathrm{~m}$ in depth constitute the fourth, third, 


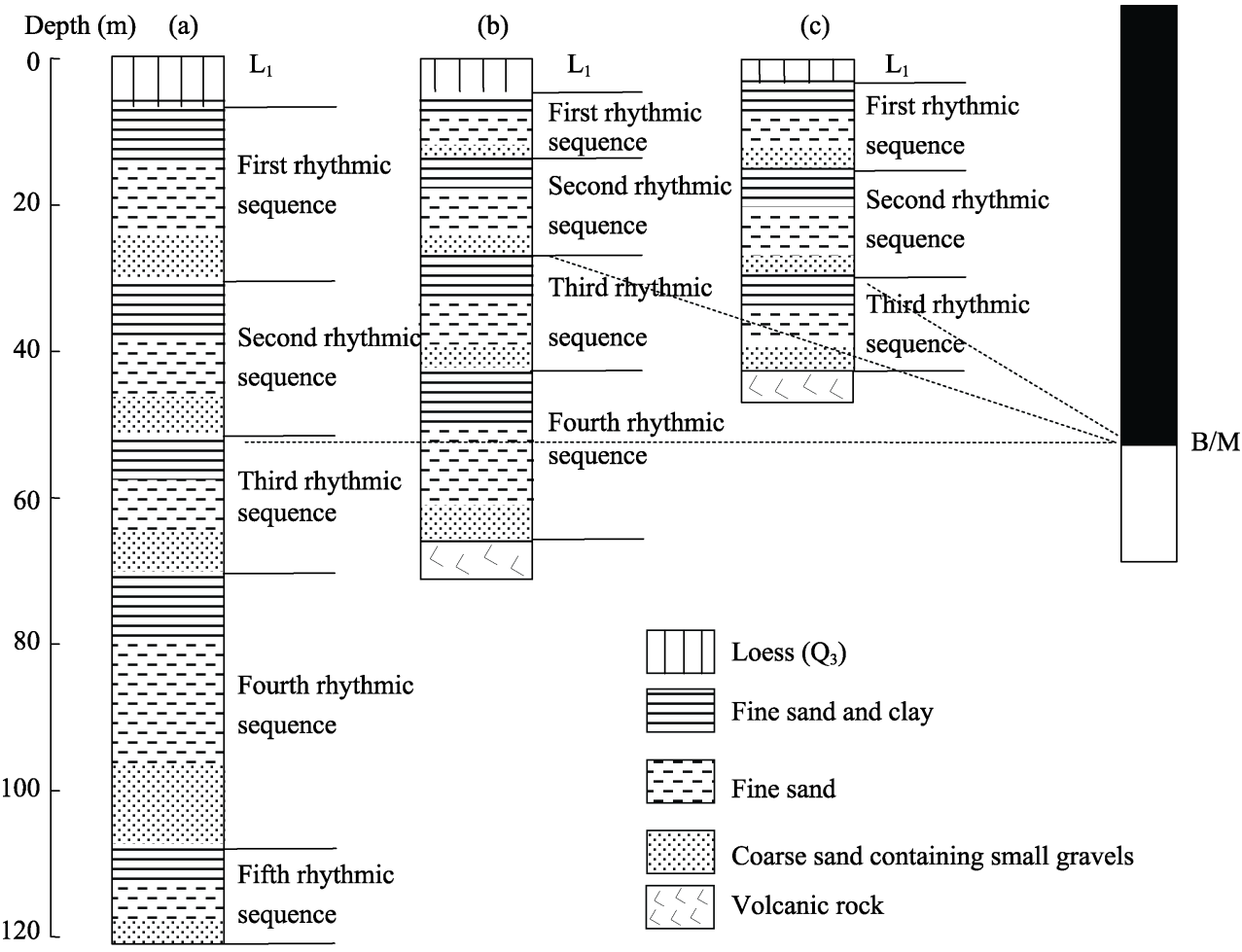

Figure 5 The rhythm and magnetic polarity of several lacustrine sediment sections in the Datong Basin a. Haojiatai Section, b. Xiaochangliang Section, c. Donggutuo Section

second and first sedimentary rhythmic sequences, respectively. Overlying the lacustrine sediment is a $\sim 7 \mathrm{~m}$ thick layer loess $\mathrm{L}_{1}$. Paleomagnetic results show that the $\mathrm{B} / \mathrm{M}$ boundary is also located at the base of the second sedimentary rhythmic sequence. The Donggutuo Section is $\sim 44 \mathrm{~m}$ in depth, and its base is also composed of volcanic rock; three sedimentary rhythmic cycles can be identified within the section. The sedimentary layers from $44.3 \mathrm{~m}$ to $30.2 \mathrm{~m}, 30.2 \mathrm{~m}$ to $18.1 \mathrm{~m}$, and $18.1 \mathrm{~m}$ to $7.1 \mathrm{~m}$ in depth constitute the third, second and first sedimentary rhythmic sequences, respectively. $\mathrm{A} \mathrm{L}_{1}$ layer $\sim 7 \mathrm{~m}$ thick overlies the lacustrine sediment. The B/M boundary is located at the base of the second sedimentary rhythmic sequence. Magnetostratigraphic dating of the loess/paleosol sequence typical of northwestern China indicates that the $\mathrm{B} / \mathrm{M}$ boundary is located in loess $\mathrm{L}_{8}$ (Yue and Xue, 1996). This would indicate that the onset time of the second sedimentary rhythmic sequence in these three sections is synchronous with $\mathrm{L}_{8}$.

Assuming that the duration of the deposition of every sedimentary rhythmic sequence is proportional to its thickness, an estimation of the onset time of the first sedimentary rhythmic sequence was made. Because the $\mathrm{B} / \mathrm{M}$ boundary is located at the base of the second sedimentary rhythmic sequence, and the first one is capped by $\mathrm{L}_{1}$, we took the age of the $\mathrm{B} / \mathrm{M}$ boundary to be $0.73 \mathrm{MaBP}$, and that of $\mathrm{L}_{1}$ to be $0.07 \mathrm{MaBP}$ (Liu et al., 1994; Ding et al., 1994; Yue and Xue, 1996). The onset time of the first sedimentary rhythmic sequence can be calculated using the formula $\mathrm{D}=\mathrm{H}_{1} / \mathrm{H}_{1+2} \times(0.73-0.07)+0.07$ (D: the onset time of the first sedimentary rhythmic sequence; $\mathrm{H}_{1}$ : the thickness of the first sedimentary rhythmic sequence; $\mathrm{H}_{1+2}$ : the total thickness of the first and the second sedimentary rhythmic sequences). Results show that the onset times of the first sedimentary rhythmic sequence in the Haojiatai, 
Xiaochangliang and Donggutuo sections are $\sim 0.464 \mathrm{MaBP}, 0.417 \mathrm{MaBP}$ and $0.384 \mathrm{MaBP}$, respectively. Loess $\mathrm{L}_{5}$ was deposited between $\sim 0.482 \mathrm{MaBP}$ and $0.418 \mathrm{MaBP}$ (Ding et al., 1994), so it can be inferred that the onset time of the first sedimentary rhythmic sequence is nearly synchronous with $\mathrm{L}_{5}$.

\section{Temporal differences in the episodic geomorphological-sedimentary evolution of the basins in the Fenwei Graben}

In the $\mathrm{WB}$, the oldest loess/paleosol units overlying the terraces $\mathrm{T}_{5}, \mathrm{~T}_{4}$ and $\mathrm{T}_{3}$ in the upper reaches of the Weihe River indicate that the river experienced three intensive down-incisions when $\mathrm{L}_{9}, \mathrm{~L}_{6}$ and $\mathrm{L}_{2}$ were depositing, respectively. In the river's lower reaches, the existence of two lacustrine terraces indicates that the paleolake experienced two significant regressions when $\mathrm{L}_{6}$ and $\mathrm{L}_{2}$ were depositing. The height differences between the terraces demonstrate that both paleolake regressions saw drops in their levels of $>20 \mathrm{~m}$. The two lacustrine terraces correspond temporally to the alluvial terraces $T_{4}$ and $T_{3}$ in the river's upper reaches. This shows that three episodic intensive stream down-incisions and/or substantial paleolake regressions occurred in the WB during the Mid-Late Quaternary.

In the LB, the two transverse geomorphological-sedimentary sections show that four paleolake regressions occurred during the Mid-Late Quaternary. The first paleolake regression occurred when $\mathrm{S}_{8}$ began to develop. The drop in paleolake levels during this regression is calculated to be $\sim 40-50 \mathrm{~m}$, based on the height difference between the two adjacent terraces. The second paleolake regression occurred when $\mathrm{S}_{5}$ began to develop. This regression caused the paleolake level to decline $>60 \mathrm{~m}$, and may have left the southern sector of the basin empty, because $S_{5}$ extends nearly to the center of this sector. The third paleolake regression occurred when $\mathrm{S}_{2}$ began to form; sedimentary evidence shows there was a drop in the paleolake levels of $\sim 10 \mathrm{~m}$. The fourth paleolake regression took place when $\mathrm{S}_{1}$ began to form. This regression was so extensive that nearly all the lakewater drained away so that the paleolake effectively disappeared, with the Fen River emerging in the lowest part of the basin. The paleolake regressions found in the LB are also recorded in the TB, with the exception of the third one. In the $\mathrm{XB}$, only two lake regressions corresponding to the first and third ones in the LB are apparent, and the others have not been yet been identified in the field. Each of the lake regressions in the $\mathrm{TB}$ and $\mathrm{XB}$, based on the height differences between adjacent terraces, shows drops in paleolake levels exceeding several tens of meters. We can therefore infer that four episodic paleolake regressions occurred in the LB, TB and XB during the Mid-Late Quaternary.

Changes in the sedimentary rhythms in the DB show that several paleolake regression-transgression cycles occurred during the Mid-Late Quaternary. The last two sedimentary rhythmic sequences show that the onset times of the last two paleolake regressions are synchronous with the deposition of $\mathrm{L}_{8}$ and $\mathrm{L}_{5}$, respectively. The lacustrine sediment in the basin is extensively capped by $\mathrm{L}_{1}$, indicating that a significant regression, ending with the disappearance of the paleolake, occurred when $\mathrm{L}_{1}$ began to deposit. Therefore, three episodic paleolake regressions took place in the basin during the Mid-Late Quaternary.

These findings reveal that there are temporal differences in the episodic paleolake regressions and/or intensive stream down-incisions in this series of basins in the Fenwei Graben, except for the paleolake regression occurring in the LB when $\mathrm{S}_{2}$ began to develop. In the 
$\mathrm{WB}$, three of the intensive stream down-incisions and/or paleolake regressions occurred when $\mathrm{L}_{9}, \mathrm{~L}_{6}$ and $\mathrm{L}_{2}$ were depositing, respectively; in the $\mathrm{LB}$, TB and $\mathrm{XB}$, three of the paleolake regressions took place when $\mathrm{S}_{8}, \mathrm{~S}_{5}$ and $\mathrm{S}_{1}$ began to develop, respectively; in the DB, three paleolake regressions occurred synchronously with each of the formations of $\mathrm{L}_{8}, \mathrm{~L}_{5}$ and $\mathrm{L}_{1}$, respectively. From the $\mathrm{WB}$, through the $\mathrm{LB}, \mathrm{TB}$ and $\mathrm{XB}$, to the $\mathrm{DB}$, the occurrence of the lake regressions and/or intensive stream down-incisions in each of the three episodes grows later and later, displaying temporal differences between $\mathrm{L}_{9}-\mathrm{S}_{8}-\mathrm{L}_{8}, \mathrm{~L}_{6}-\mathrm{S}_{5}-\mathrm{L}_{5}$, and $\mathrm{L}_{2}-\mathrm{S}_{1}-\mathrm{L}_{1}$, respectively. In other words, the farther the basin is from the TP, the later the episodic geomorphological-sedimentary event occurred.

\section{Discussion}

The episodic geomorphological-sedimentary evolution in the Graben was not the result of paleoclimate changes. This is because: 1) the occurrences of several lake regressions in the LB, TB and XB are almost synchronous with the formation of some paleosols, when the paleoclimate was warm and wet and was accompanied by high annual precipitation, raising paleolake levels (An et al., 1991b, Porter and An, 1995); 2) although several paleolake regressions in the WB and DB occurred when some loess units were depositing and the paleoclimate was dry, the other episodes of loess deposition did not cause regressions and paleolake regressions identified do not coincide with the dry-wet climate changes recorded by loess-paleosol sequences during the Quaternary; 3) there are no calcium carbonate crystals on the surface of each lacustrine terrace, indicating that the paleoclimate was not dry enough to make the lake levels regress significantly; and 4) previous research has shown that paleoclimate changes during the Mid-Late Quaternary brought about only minor paleolake level fluctuations of $\sim 2-3 \mathrm{~m}$ in these outflow basins (Hu et al., 2005). All these factors suggest that not climate but tectonic movement may be the primary factor affecting episodic geomorphological-sedimentary evolution in the Graben.

Although the Fenwei Graben is located between the subduction zone of the western Pacific Plate and the TP, some researches have suggested that the regional tectonic stress field and tectonic movement in north and northwest China (including the Fenwei Graben) during the Cenozoic were both strongly controlled by the movement of the TP, and were little related to the northwestward subduction of the western Pacific Plate (Zhang et al., 1979; Chen, 1987; Zhu et al., 2000; Shi et al., 2015). Other studies (Wang, 1979, Deng et al., 1982) have indicated that the development of the Graben is closely related to the upper mantle uplift underneath the Graben, causing the basins to extend orthogonally. Based on these facts, we deduce that the episodic geomorphological-sedimentary evolution in the Graben is most probably controlled by the tectonic movement of the TP.

There are two hypotheses concerning the nature of the tectonic movement of the TP. One is called "crustal thickening" (England and Houseman, 1986), and the other is called "lithosphere extrusion" (Tapponnier et al., 1982; Lavé et al., 1996). Both state that an intensive movement of viscous material beneath the TP occurred during the collision of the Indian and Eurasian plates. The collision of the two plates would have forced the upper mantle material underneath the TP to move in an outward direction, and some of it may have moved northeastward and then moved upward along the Fenwei Graben where the geological structure is much fractured. The teleseismic tomography and magnetic anomalies identified along 
northern and northeastern margins of the TP even show that the deep materials there mainly flow northward and northeastward (Wittlinger et al., 1996; Gao et al., 2015); the uplifted Moho, high heat flow and volcano eruptions in the Fenwei Graben all indicate the existence of such upward movement (Li et al., 1998; Wang et al., 2014; Gao et al., 2015). Because the basins in the graben were all outflow lakes during the Quaternary, intensive upward movement of upper mantle material in depth of the graben basins would raise the basins' floors to drain much water and caused lake regressions (Chen and $\mathrm{Hu}, 2017$ ). We speculate that it is this process which resulted in some geomorphological-sedimentary changes in the Graben's basins. Because of the differences in distances from the TP, the time when the upward movement of the upper mantle material occurred is different in different basins; the farther it is from the TP, the later the upward movement of the upper mantle material.

\section{Conclusions}

Except for the paleolake regression which took place in the LB when $\mathrm{S}_{2}$ began to develop, there are three significant episodic paleolake regressions and/or intensive stream down-incisions in the WB, LB, TB, XB and DB in the Fenwei Graben during the Mid-Late Quaternary. In the WB, there occurred three intensive down-incisions or paleolake regressions when $\mathrm{L}_{9}, \mathrm{~L}_{6}$ and $\mathrm{L}_{2}$ were depositing, respectively; in the $\mathrm{LB}$, TB and $\mathrm{XB}$, three paleolake regressions took place when $\mathrm{S}_{8}, \mathrm{~S}_{5}$ and $\mathrm{S}_{1}$ were developing, respectively; in the $\mathrm{DB}$, three paleolake regressions occurred synchronously with the deposition of $\mathrm{L}_{8}, \mathrm{~L}_{5}$ and $\mathrm{L}_{1}$, respectively. There are temporal differences in each of the three episodic paleolake regressions and/or intensive down-incisions in these basins. The farther the basin is from the TP, the later the onset time of each of the three paleolake regressions and/or intensive river down-incisions.

These paleolake regressions and/or intensive river down-incisions were caused by regional tectonic movement, not paleoclimate changes, and the tectonic movement of the TP has probably played a most important role in the Graben's episodic geomorphological-sedimentary evolutions.

\section{References}

An Z S, Kukala G, Proter S C, 1991a. Late Quaternary dust flow on the Chinese Loess Plateau. Catena, 18: $125-132$.

An Z S, Kukla G J, Porter S C et al., 1991b. Magnetic susceptibility evidence of monsoon variation on the Loess Plateau of central China during the last 130,000 years. Quaternary Research, 36(1): 29-36.

An Z S, Kutzbach J E, Prell W L et al., 2001. Evolution of Asian monsoons and phased uplift of the Himalaya-Tibetan Plateau since Late Miocene times. Nature, 411: 62-66.

Chen G D, 1987. On the geotectonic nature of the Fen-Wei rift system. Tectonophysics, 143(1-3): 217-223.

Chen M J, Hu X M, 2017. Regression-transgression cycles of paleolakes in the Fen River Graben Basin during the mid to late Quaternary and their tectonic implication. Frontiers of Earth Science, doi: 10.1007/s11707-016-0598-8.

Coleman M, 1995. Evidence for Tibetan uplift before 14 Myr ago from a new minimum age for east-west extension. Nature, 374: 49-52.

Cui Z J, Wu Y Q, Liu G N et al., 1998. On Kunlun-Yellow River tectonic movement. Science in China Series D: Earth Sciences, 41(6): 592-600.

Deng Q D, Zhang Y M, Xu G L et al., 1982. The characteristics of neotectonic stress field in China and its rela- 
tionship with the intra-plate movement. Seismic Geology, 1(1): 11-22. (in Chinese)

Ding Z L, Yu Z, Rutter N W et al., 1994. Towards an orbital time scale for Chinese loess deposits. Quaternary Science Reviews, 13(1): 39-70.

England P, Houseman G A., 1986. Finite strain calculations of continental deformation, 2, Comparison with the India-Asia collision. $J$ Geophys Res., 91: 3664-3667.

Gao G M, Kang G F, Li G Q et al., 2015. Crustal magnetic anomaly in the Ordos region and its tectonic implications. Journal of Asian Earth Sciences, 109: 63-73.

Han J T, Fyfe W S, Longstaffe F J, 1998. Climatic implications of the $\mathrm{S}_{5}$ Paleosol complex on the southernmost Chinese Loess Plateau. Quaternary Research, 50(1): 21-33.

Harrison T M, Copeland P, Kidd W S F et al., 1992. Raising Tibet. Science, 255: 1663-1670.

Hu X M, Li Y L, Yang J C, 2005. Quaternary paleolake development in the Fen River basin, North China. Geomorphology, 65(1/2): 1-13.

Hu X M, Wang L L, Zhe J et al., 2010. Morpho-sedimentary evidence of the Huoshan Fault's late Cenozoic right-lateral movement in the Linfen Graben. Shanxi Graben System, North China. Frontiers of Earth Science, 4(3): 311-319.

Hu Z B, Pan B T, Gao L Y et al., 2016. Rapid fluvial incision and headward erosion by the Yellow River along the Jinshaan gorge during the past 1.2 Ma as a result of tectonic extension. Quaternary Science Reviews, 133: $1-14$.

Kukla G, An Z S, 1989. Loess stratigraphy in central China. Palaeogeography, Palaeoclimatology, Palaeoecology 72: 203-223.

Lavé J, Avouac J P, Lacassin R et al., 1996. Seismic anisotropy beneath Tibet: Evidence for eastward extrusion of the Tibetan lithosphere? Earth and Planetary Science Letters, 140(1-4): 83-96.

Li J J, Fang X M, Ma H Z et al., 1996. Geomorphologic and environmental evolution in the upper reaches of the Yellow River during the Late Cenozoic. Science in China Series D: Earth Sciences, 39: 380-390. (in Chinese)

Li J J, Fang X M, Song C H et al., 2014. Late Miocene-Quaternary rapid stepwise uplift of NE Tibetan Plateau and its effects on climate and environmental changes. Quaternary Research, 81(3): 400-423.

Li Y L, Yang J C, Xia Z K et al., 1998. Tectonic geomorphology in the Shanxi Graben System, northern China. Geomorphology, 23(1): 77-89.

Liu D S, 1985. Loess and the Environment. Beijing: China Ocean Press. (in Chinese)

Liu J Q, Cheng T M, Ni G Z, 1994. The dating of Weinan loess section and the construction of its series in time. Quaternary Sciences, 3: 193-200. (in Chinese)

Mo D W, 1991. The study on the paleoenvironmental evolution in the Linfen Basin during the Cenozoic. The Journal of Peking University (Natural Science), 27 (6): 25-29. (in Chinese)

Pan B T, Hu Z B, Wang J P et al., 2011. A magnetostratigraphic record of landscape development in the eastern Ordos Plateau, China: Transition from Late Miocene and Early Pliocene stacked sedimentation to Late Plocene and Quaternary uplift and incision by the Yellow River. Geomorphology, 125(1): 225-238.

Pan B T, Hu Z B, Wang J P et al., 2012. The approximate age of the planation surface and the incision of the Yellow River. Palaeogeography, Palaeoclimatology, Palaeoecology, 356/357: 54-61.

Porter S C, An Z S, 1995. Correlation between climate events in the North Atlantic and China during the last glaciation. Nature, 375: 305-308.

Porter S C, An Z S, Zheng H B, 1992. Cyclic Quaternary alluviation and terracing in a nonglaciated drainage basin on the north flank of the Qinling Shan, Central China. Quaternary Research, 38(2): 157-169.

Qu W, Lu Z, Zhang Q et al., 2014. Kinematic model of crustal deformation of Fenwei basin, China based on GPS observations. Journal of Geodynamics, 75: 1-8.

Research Group of State Seismological Bureau (RGSSB), 1988. Active Fault System around Ordos Massif. Beijing: Seismic Press, 77-113, 238-246. (in Chinese)

Shen J, Lu H Y, Wang S M et al., 2004. A 2.8 Ma record of environmental evolution and tectonic events inferred from the Cuoe Core in the middle of Tibetan Plateau. Science in China Series D: Earth Sciences, 47(11): $1025-1034$. 
Shi W, Dong S W, Liu Y et al., 2015. Cenozoic tectonic evolution of the south Ningxia region, northeastern Tibetan Plateau inferred from new structural investigations and fault kinematic analyses. Tectonophysics, 649: $139-164$.

Tang Y J, Li Y, Chen W Y, 1995. Mammalian fossils and the age of Xiaochangliang Paleolithic site of Yangyuan, Hebei. Vertebrata Pal Asiatica, 33(1): 74-83.

Tapponnier P G, Peltzer A Y, Dain L, 1982. Propagating extrusion tectonics in Asia: New insights from simple experiments with plasticine. Geology, 10: 611-616.

Wang J M, 1987. The Fenwei rift and its recent periodic activity. Tectonophysics, 133(3/4): 257-275.

Wang N L, Yang J C, Xia Z K, 1996. The Sediment and Tectonic Landform during Cenozoic in the Fen River Drainage Basin. Beijing: Science Press. (in Chinese)

Wang P, Huang Z C, Mi N et al., 2014. Crustal structure beneath the Weihe Graben in central China: Evidence for the tectonic regime transformation in the Cenozoic. Journal of Asian Earth Science, 81: 105-114.

Wang S M, Wu X H, Zhang Z K et al., 2001. Environmental evolution recorded by the lacustrine sediment in the Sanmen Paleolake and the formation of Yellow River. Science in China Series D: Earth Sciences, 31(9): 760-768. (in Chinese)

Wang Y M, 1979. The earthquakes in the intra-plate in China and the features of the stress field in the Mesozoic and Cenozoic. Seismology and Geology, 1(3): 1-11. (in Chinese)

Wittlinger G, Masson F, Poupinet F et al., 1996. Seismic tomography of northern Tibet and Kunlun: Evidence for crustal blocks and mantle velocity contrasts. Earth and Planetary Science Letters, 139(1/2): 263-279.

Wu Y Q, Cui Z J, Liu GN et al., 2001. Quaternary geomorphological evolution of the Kunlun Pass area and uplift of the Qinghai-Xizang (Tibet) Plateau. Geomorphology, 36(3/4): 203-216.

Xia Z K, 1992. The study on the change of ancient lake shore of Datong-Yangyuan Basin. Geographical Research 11(2): 52-59. (in Chinese)

Xue B, Wang S M, Xia W L et al., 1998. The uplifting and environmental change of Qinghai-Xizang (Tibetan) Plateau in the past $0.9 \mathrm{Ma}$ inferred from Core RM of Zoige Basin. Science in China Series D: Earth Sciences, 41(2): 165-170.

Yang C S, Zhang Q, Zhao C Y et al., 2014. Monitoring land subsidence and fault deformation using the small baseline subset InSAR technique: A case study in the Datong Basin, China. Journal of Geodynamics, 75: 34-40.

Yang X Q, 2000. The comprehensive study on the sequence stratrography and magnetostratigraphy on the Nihewan Formation [D]. Guangzhou: Institute of Guangzhou Geochemistry, Chinese Academy of Sciences. (in Chinese)

You Y Z, Tang Y J, Li Y, 1980. Discovery of the Paleoliths from the Nihewan Formation. Quaternary Sciences, 5(1): 1-13. (in Chinese)

Yue L P, Xue X X, 1996. China Loess and Paleomagnetism. Beijing: Geology Press. (in Chinese)

Zhang A L, Yang Z T, Zhong J et al., 1995. Characteristics of late Quaternary activity along the southern border fault zone of Weihe Graben Basin. Quaternary International, 25: 25-31.

Zhang Y M, Wang L M, Dong R S, 1979. Discussion on the changes of Cenozoic tectonic stress field in the eastern part of north China. Seismology and Geology, 1(1): 23-28. (in Chinese)

Zhang Y Q, Mercier J L, Vergely P, 1998. Extension in the graben system around the Ordos (China), and its contribution to the extrusion tectonics of south China with respect to Gobi-Mongolia. Tectonophysics, 285(1/2): $41-75$.

Zhu R X, Hoffman K A, Potts R et al., 2001. Earliest presence of humans in northeast Asia. Nature, 413: 413-417.

Zhu R X, Potts T, Xie F et al., 2004. New evidence on the earliest human presence at high northern latitudes in northeast Asia. Nature, 431: 559-562.

Zhu W Y, Wang X Y, Cheng Z Y et al., 2000. Crustal motion of Chinese mainland monitored by GPS. Science in China Series D: Earth Sciences, 43(4): 394-400. 